\title{
RUNTUHNYA MARXISME-LENINISME DI UNI SOVIET DALAM TEORI ASHABIYAH IBNU KHALDUN
}

\section{Emil Dwi Febrian}

Fakultas Pascasarjana, Universitas Sebelas Maret

Email: dftemil@gmail.com

\section{Susanto}

Fakultas Pascasarjana, Universitas Sebelas Maret

\section{Sri Kusumo Habsari}

Fakultas Pascasarjana, Universitas Sebelas Maret

\section{Abstrak}

Artikel ini mengkaji sejarah runtuhnya Uni Soviet dengan teori ashabiyah Ibnu Khaldun. Uni Soviet adalah negara berideologi komunis atau sosialis-Marxis pertama yang berdiri di tahun 1922, setelah lengsernya kekuasaan Monarki-Rusia akibat krisis dan gerakan saparatis tahun 1917. Pasca Perang Dunia II, Uni Soviet menjadi kiblat bagi gerakan komunis di seluruh dunia, dan maju di bidang industri hingga dikenal sebagai negara adidaya di abad ke-20 selain Amerika Serikat. Namun secara mengejutkan Uni Soviet dinyatakan runtuh pada tahun 1991. Dalam artikel ini ditemukan bahwa teori ashabiyah Ibn Khaldun bisa menjelaskan sejarah Uni Soviet dalam tiga tahap metamorfosis negara, yaitu tahap terbentuknya, tahap kejayaannya, dan tahap keruntuhannya. Ashabiyah berarti suatu ikatan yang mempersatukan rakyat, namun bisa bersifat positif dan negatif. Melalui analisis menggunakan ashabiyah negatif, disimpulkan bahwa runtuhnya Marxisme-Leninisme di Uni Soviet dikarenakan pendogmaan terhadap ajaran filosofis ini yang dilakukan untuk menciptakan hak istimewa Partai Komunis yang menjadi rezim otoriter, yang akhirnya dianggap tidak relevan dan ditentang oleh masyarakat. Otoritarianisme di Uni Soviet terjadi karena eksklusivisme dan kultus. Setelah dilakukan reflesksi, ditemukan bahwa otoritarianisme bisa terjadi di negara non-komunis, 
termasuk Indonesia di era Orde Baru, hal ini menunjukan bahwa bukan ideologi yang berpengaruh dalam terciptanya rezim otoriter, tetapi praktik politik di negara tersebut.

Kata kunci: Uni Soviet, Marxisme, Adidaya, Ibnu Khaldun, Teori Ashabiyah.

\section{Abstract}

This article examines history collapse of the Soviet Union with Ibn Khaldun's ashabiyah theory. The Soviet Union was first communist nation founded in 1922 after fall of the Russian-Monarchy due to the crisis and saparatist movement in 1917. Post World War II, the Soviet Union became a center of the communist movement around the world, and advanced in industrial sector, known as a superpower nation in the 20th century beside the United States. However, the Soviet Union was declared collapsed in 1991. This article found that Ibn Khaldun's ashabiyah can explain history of the Soviet Union in three stages of state metamorphosis; formation, glory, and collapse. Ashabiyah means a bond that unites the people, but it can be positive and negative. Analysis with negative ashabiyah, concluded that the collapse of Marxism-Leninism in Soviet Union was due to the denial of this philosophical teaching to create the privileges of the Communist Party became an authoritarian regime, and considered irrelevant and opposed by society. Authoritarianism happaned because of exclusivism and cult, and could occur in non-communist nations, including Indonesia in the New Order era, this shows that it is not ideology that created of authoritarian regimes, but political practices in specific nations.

Keywords: Soviet Union, Marxism, Superpowers, Ibn Khaldun, Ashabiyah Theory.

\section{PENDAHULUAN}

Setelah Perang Dunia II berakhir ada dua negara yang dianggap sebagai negara adidaya, yaitu Amerika Serikat dan Uni Soviet yang sebelumnya tergabung sebagai anggota Sekutu dalam melawan NAZI Jerman. Hubungan Amerika Serikat dan Uni Soviet yang semula adalah kawan berubah menjadi lawan karena 
ideologi dan sistem ekonomi dianggap bertentangan (Mujiyanti, et al, 2016:40). Amerika Serikat yang menerapkan sistem kapitalisme adalah lawan bagi sistem komunisme di Uni Soviet. Kedua negara masing-masing beranggapan bahwa ideologi mereka adalah yang paling baik dilaksanakan oleh masyarakat di seluruh dunia, dan karena hal tersebut terjadi perlombaan untuk menyebarkan ideologi kepada negara-negara terutama yang baru merdeka pasca Perang Dunia II.

Penyebaran ideologi yang dilaksanakan Amerika Serikat dan Uni Soviet ternyata menghasilkan konflik di negara lain, sebagai contonya; Korea terbagi menjadi dua wilayah negara, yaitu komunis di utara dan kapitalis di selatan yang bertahan sampai sekarang. Jerman sempat terpecah menjadi Jerman Barat yang kapitalis dan Jerman Timur yang komunis. Perang Sipil Vietnam terjadi karena wilayah utara mendukung komunisme dan selatan mendukung kapitalisme yang berlangsung selama tiga dekade sejak tahun 1955 hingga tahun 1975. Sementara di Indonesia terjadi Peristiwa Madiun 1948 dan G30SPKI yang masih memiliki kaitan dengan perdebatan ideologi yang disebarkan dua negara adidaya tersebut.

Konflik ideologi antara Amerika Serikat dan Uni Soviet menjadi ketakutan internasional bukan hanya terkait pengaruhnya yang menimbulkan pertikaian di negara lain, namun juga karena keinginan dua negara itu menguasai teknologi nuklir untuk menciptakan senjata pemusnah masal yang bahayanya dapat dilihat pada Hiroshima dan Nagasaki di tahun 1945. Timbunan senjata nuklir ciptaan dua negara itu cukup untuk membunuh 12 kali jumlah penduduk dunia. Lebih menakutkan lagi, senjata nuklir memiliki daya pemusnah dengan efek samping yang memakan waktu panjang sampai generasi turun-temurun (Mutarmadji, 2009:82). Bagi mereka yang hidup di dekade 1950-an sampai akhir 1980-an, ketakutan ini dikenal dengan istilah Perang Dingin.

Sebagaimana banyak catatan sejarah mengenai peradaban maju di masa lalu, kemajuan peradaban atau suatu negara tidak 
pernah abadi. Di masa Gorbachev ketika memerintah, yaitu di pertengahan 1980-an, tanda-tanda runtuhnya Uni Soviet dan ideologi komunis mulai terasa. Banyak negara Blok Timur atau yang juga dikenal dengan Pakta Warsawa ingin bebas dari kekuasan tunggal partai-partai berhaluan komunis, padahal dulunya negara-negara tersebut begitu loyal mendukung ideologi komunisme yang berakar dari filsafat Marxisme-Leninisme, dengan Uni Soviet sebagai kiblatnya. Puncaknya pada tahun 1989, saat masyarakat Jerman Timur memaksa untuk meruntuhkan tembok berlin agar terbebas dari pemerintah komunis (Kurniawati, 2015:3). Runtuhnya tembok berlin adalah simbol dari runtuhnya komunisme di Eropa.

Dalam kisruh-kisruh runtuhnya komunisme di berbagai negara anggota Blok Timur, masyarakat Uni Soviet mulai merasakan bahwa pijakan ideologi dan ekonomi berdasarkan ajaran Karl Marx tidak lagi relevan dengan keadaan sosial Eropa Timur di akhir abad ke-20. Kapitalisme yang semula dianggap Marx akan menghancurkan dirinya sendiri ternyata malah semakin kuat karena dapat menyesuaikan zaman dengan cara menciptakan kebutuhan-kebutuhan artifisial yang dianggap perlu oleh masyarakat. Masyarakat dari kalangan pekerja kasar yang dianggap Marx akan melawan hirarki kapitalisme ternyata malah semakin larut dalam hegemoni kebebasan berbelanja yang ditawarkannya. Lalu, apa yang membuat Marx gagal dalam teorinya?

Filsafat Marx berangkat dari aliran materialisme yang menganggap segala sesuatu di alam ini adalah materi dan gerak (Isma'il \& Mutawalli, 2016:132). Aliran ini adalah reaksi dari aliran idealisme yang dianggap hanya menyimpulkan segala hal pada kesadaran abstrak. Karl Marx (dalam Ramly, 2000:34), pernah menulis: "Bukanlah kesadaran manusia yang menentukan adanya mereka, tetapi sebaliknya, adalah penghidupan sosial (ekonomi) mereka yang menentukan kesadaran". Materialisme yang dikembangkan oleh Karl Marx dan Friedrich Engels memiliki perhatian utama kepada hubungan manusia dan ekonomi, 
sehingga untuk mendapatkan kebahagiaan yang paling fundamental hanya sekadar perkara terpenuhinya kebutuhan material, karena itu manusia harus berusaha untuk membangun suatu sistem baru yang mengatur kehidupan di dunia yang sifatnya material ini (Nonci, 2012:34).

Karl Marx dalam Manifesto Partai Komunis juga menulis: "Sejarah dari semua masyarakat yang ada hingga sekarang ini adalah sejarah perjuangan kelas" (Marx \& Engels, 2009:2). Bagi Marx, dunia sejak lahirnya masa modern atau masyarakat industri dikuasai oleh mereka yang memiliki modal ekonomi dan membuat berbagai pabrik-pabrik, di mana mereka yang tidak memiliki modal terpaksa menjadi pekerja dengan upah yang tidak layak, sementara mereka yang memiliki modal mengambil untung yang tak sedikit dari hasil produksi para pekerja. Ide Marx untuk mengatasi kesewenangan pemilik modal adalah revolusi mewujudkan negara sosialis.

Sosialisme secara umum bermula sebagai kumpulan pemikiran yang menentang individualisme (Giddens, 2000:3). Dengan menentang individualisme diharapkan masyarakat dapat berubah untuk saling bekerja sama dalam membangun negara, karena hal tersebut maka kepemilikan pribadi terhadap tanah dan benda dalam doktrin sosialis diubah menjadi kepemilikan bersama. Namun bagi Marx, dokrtin sosialisme semacam itu dianggap tidak lengkap dan tidak peka pada keadaan masyarakat yang sebenarnya, terutama mengenai kesenjangan kelas. Marx memimpikan revolusi negara sosialis yang diprakasai oleh masyarakat dari kelas yang tertindas, terasingkan, atau dalam bahasanya teralienasi secara materi dan sosial untuk bersatu (bergerak dengan nyata) melawan ketidakadilan dari kelas masyarakat berkuasa. Masyarakat tertindas yang dimaksud adalah kaum proletar yang harus menjatuhkan kesewenang-wenangan kaum borjuis. Mereka adalah buruh atau pekerja kasar, mereka yang secara ekonomi hanya mendapat sedikit dengan kerja yang banyak. Marx menutup kata dalam Manifesto Partai Komunis dengan "Kaum buruh sedunia, bersatulah!" (Marx \& Engels, 
2009:44). Singkatnya, bagi Marx jika suatu saat kaum proletar berkuasa setelah melengserkan kekuasaan kaum borjuis, maka dunia yang penuh harmoni tanpa hirarki akan tercipta. Seperti yang dikatakan Romo Magnis-Suseno(2013:2-3):

"Manifesto Komunis tidak hanya menjelaskan kepada kaum tertindas seluruh dunia bahwa merekalah yang akan mengakhiri penindasan itu. Manifesto Komunis memberi kebanggaan kepada orang-orang yang tangannya kotor berdebu, kotor minyak, kotor batu bara, bahwa merekalah yang sebenarnya menciptakan segala kekayaan yang dibanggakan kapitalisme".

M. Karim dan B.O. Smith (dalam Ramly, 2000:81) mengatakan "Marx adalah seorang deteminis dalam arti yang sesungguhnya dari aliran determinisme historis abad ke-19", karena itulah ide Marx akhirnya gagal di Eropa Timur akhir abad ke-20. Marx belum memahami jika suatu rezim yang dianggap oleh pendukungnya paling adil, oleh oposisinya akan dianggap sebagai musuh yang harus dilawan, karena keadilan yang dipahami sebetulnya adalah legitimasi atas kekuasaan dari suatu kelompok terhadap kelompok yang lain. Seperti yang diungkapkan dua filosof besar dipertengahan abad ke-20 yang menggali kembali pemikiran Marx, yaitu Horkhaimer dan Adorno, "kekuasaanlah yang memperbudak dan memperalat akal" yang lalu dikembangkan Foucault (dan pemikir postmodernisme lain) "bahwa kekuasaanlah yang mempunyai naluri untuk kembali dan bertambah kuasa lagi" (Sindhunata, 2000:9).

Marx selama hidupnya memang tidak pernah memimpin suatu revolusi berdasarkan ide yang ditulisnya, tetapi tulisannya telah mempengaruhi Vladimir Lenin untuk mendirikan Partai Komunis yang memiliki peran dalam melengserkan kekuasaan Tsar di Kekaisaran Rusia tahun 1917. Bisa dikatakan Lenin yang membuat ide Marx tidak lagi hanya sebagai teori, tetapi sudah menjadi praksis. Pada tahun 1922, beberapa tahun setelah runtuhnya kekaisaran Rusia, Lenin yang awalnya hanya pimpinan 
dari kaum Bolshevik atau Partai Komunis, mengangkat dirinya sendiri untuk menjadi pemimpin tertinggi dari negara baru bernama Uni Soviet, negara sosialis-komunis pertama di awal abad ke-20. Negara yang mengukuhkan diri bersandar pada Marxisme karena telah meruntuhkan kekuasaan kaum feodal dan kaum borjuis. Lenin menulis dalam sebuah catatan berjudul Works:

"Kami tahu, dan betul-betul tahu juga berencana yang tidak ada taranya yang manakah yang akan ditimpakan peperangan kepada pekerja-pekerja dan petani-petani. Oleh sebab itu menjadilah kewajiban kami untuk mendekati persoalan itu dengan hati-hati dan penuh perhatian. Kami memberikan kelonggaran-kelonggaran yang sebesar-besarnya, tujuan kami satu-satunya adalah untuk memelihara perdamaian yang telah dibeli dengan pengorbanan yang teramat besar" (dalam Kardelj, 2001:64).

Setelah Lenin meninggal, dia digantikan oleh Stalin dan menjadikan ajaran Marx dan Lenin sebagai suatu dogma untuk melanggengkan kekuasaannya. Ajaran yang disebut dengan Marxisme-Leninisme telah menjadi semacam blueprint bagi gerakan-gerakan komunisme di seluruh dunia yang mencitacitakan revolusi hingga terbentuknya negara sosialis. Selama sebagian besar abad ke-20, komunisme menjadi salah satu kekuatan politik dan ideologis paling kuat di dunia, sepertiga umat manusia pernah hidup di bawah benderanya (MagnisSuseno, 2006:1). Tetapi secara tidak terduga Uni Soviet dinyatakan runtuh pada tanggal 21 Desember 1991.

Teori mengenai muncul dan berkembang sampai pada runtuhnya suatu negara sudah diciptakan oleh Ibnu Khaldun (1332-1406), seorang pemikir, filsuf dan sejarawan Muslim abad ke-14. Dalam teori ashabiyah, Ibnu Khaldun memberikan penjelasan-penjelasan mengenai bagaimana pemerintahan dalam suatu negara bisa mengontrol masyarakat, sekaligus juga memberikan berbagai contoh gejala-gejala yang bisa menciptakan 
suatu negara atau pemerintahan itu runtuh, gejala-gejala yang mungkin saja terjadi di Uni Soviet.

Artikel ini telah menganalisa bagaimana kemunculan, kemajuan sampai pada keruntuhan Uni Soviet dan korelasinya dengan teori ashabiyah Ibnu Khaldun. Apakah teori yang diciptakan di abad ke-14 bisa menjelaskan fenomena yang terjadi secara tidak terduga oleh masyarakat di seluruh dunia akhir abad ke-20? Artikel juga diharapkan memberi refleksi mengenai diskursus sosio-politik kekinian, karena masalah-masalah yang terjadi di Soviet pada akhir eksistensinya merupakan sebuah pelajaran yang patutnya bisa dihindari untuk terjadi kembali di masa sekarang atau yang akan datang.

\section{PEMBAHASAN}

\section{Teori Ashabiyah Ibnu Khaldun}

Ibnu Khaldun menyebut solidaritas sosial atau ikatan emosional antar individu dalam masyarakat dengan istilah ashabiyah, yaitu suatu ikatan tak terlihat yang muncul dari pola hidup suatu masyarakat. Menurutnya, ashabiyah dapat mempersatukan masyarakat untuk mencapai tujuan yang sama sekaligus untuk mengendalikanya. Ashabiyah awalnya terbentuk karena hubungan darah, lalu berkembang dengan munculnya perserikatan, persekutuan, serta organisasi. Ashabiyah memiliki tujuan untuk mencapai kedaulatan (otoritas politik) yang berfungsi sebagai kontrol sosial (Arisandi, 2015:22).

Dalam pembentukan ashabiyah, Ibnu Khaldun berpendapat bahwa agama mempunyai peran penting dalam membentuk persatuan. Semangat persatuan rakyat yang dibentuk melalui peran agama tidak bisa ditandingi oleh semangat persatuan yang dibentuk oleh faktor lainnya, karena melalui agama terjadi ikatan spiritual sebagai identitas tingkat psikologis yang abstrak (Ilham, 2016:6 dan Khaldun, 200:50).

Penerapan ashabiyah dalam suatu negara menurut Ibn Khaldun haruslah diceritakan sebagaimana keaadanya, karena 
negara yang berbudaya terbentuk melalui pembangunan dan penaklukan wilayah lain oleh masyarakat primitif yang memiliki ashabiyah yang kuat. Tujuan pembentukan negara adalah mewujudkan keinginan-keinginan alamiah dan mengaktualisasikan potensi-potensi dan kesempurnaan hidup manusia. Ashabiyah dianggap sebagai faktor esensial bagi kelanjutan negara. Besarnya suatu negara, luasnya suatu daerah dan bagaimana negara itu berpengaruh pada negara lain sangat tergatung pada ashabiyah atau rasa persatuan masyarakatnya (Khoiruddin, 2016:69).

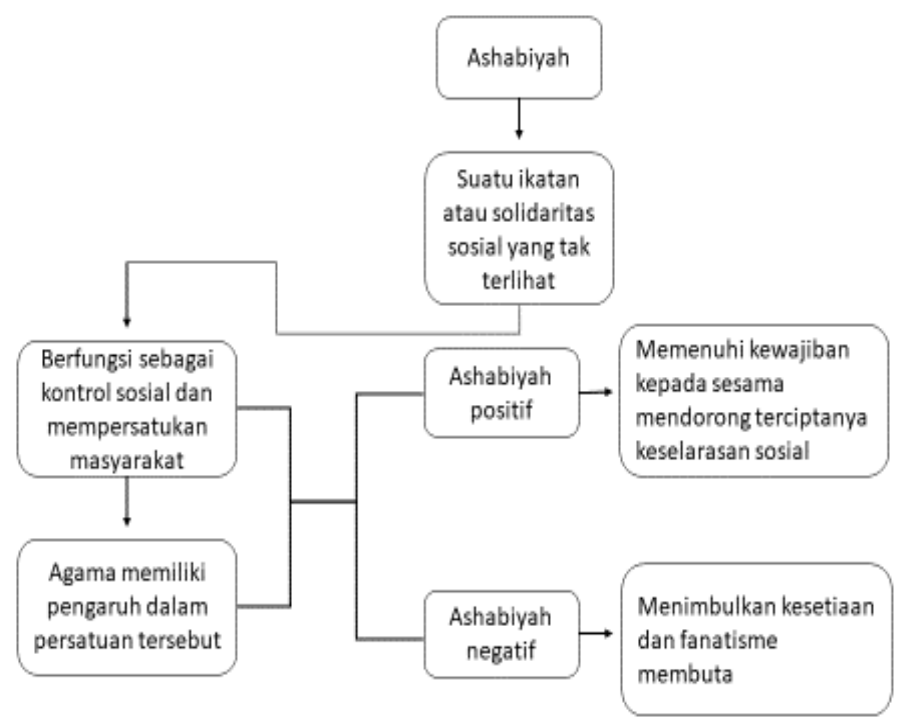

Gambar. 1. Ashabiyah

Ibnu Khaldun membagi istilah ashabiyah menjadi dua macam pengertian, yaitu ashabiyah bersifat positif dan ashabiyah bersifat negatif. Pengertian ashabiyah bersifat positif menunjuk kepada konsep persaudaraan (brotherhood), walaupun begitu persaudaraan yang dimaksud bukan terbatas hubungan sedarah melainkan hubungan komunitas yang terdiri dari berbagai individu yang memiliki tujuan dan ikatan yang sama (Khaldun, 2000:50). Tujuan dan ikatan diwujudkan dalam sistem pemerintahan negara, di mana antara pihak yang memiliki otoritas dan masyarakat biasa 
saling bekerjasama, dan memenuhi kewajiban kepada sesama agar mendorong keselarasan sosial dan kemajuan peradaban. Sementara ashabiyah bersifat negatif adalah konsep di mana masyarakat terbentuk, namun terjadi ketidakselarasan antara pihak yang memiliki otoritas dan masyarakatnya, hal tersebut dikarenakan tujuan sistem bernegara yang dilaksanakan semata untuk menciptakan fanatisme membuta kepada satu kelompok dan kepala negara hingga menimbulkan pemerintahan yang otoriter (Fajar, 2018:7).

Ashabiyah bersifat negatif dan bersifat positif sebenarnya sulit dihindarkan, karena menurut Ibnu Khaldun (2000:74), peradaban berkembang dari badawi (komunitas primitif) menjadi hadhiri (komunitas maju). Pada tahap hadhiri yang menjadi puncak peradaban suatu masyarakat justru ashabiyah negatif mudah untuk berkembang dan meruntuhkan negara itu sendiri.

Di dalam teori ashabiyah, perkembangan satu negara terbagi menjadi tiga tahapan metamorfosis; yaitu pembentukan negara, kemajuan negara dan keruntuhan negara. Tahap pertama adalah masa di mana masyarakat berada dalam keadaan primitif, namun memiliki ashabiyah atau rasa persatuan yang kuat karena cita-cita yang sama untuk membentuk negara. Tahap kedua adalah masa keberhasilan karena peradaban bisa keluar dari keadaan primitif, hingga dapat 'merebut' atau mempengaruhi negara lain. Pada tahap kedua negara mencapai hadhiri atau keadidayaan. Tahap ketiga adalah masa ketika negara mengalami kehancuran dikarenakan keadidayaan telah menciptakan perasaan takut kehilangan berbagai fasilitas hidup mewah terutama kepada golongan elit atau pemerintah. Pada tahap ketiga ini pemerintah berupaya melanggengkan kekuasaanya dengan cara apapun, hingga menjadi rezim otoriter. Di masa rezim otoriter inilah mulai muncul gerakan rakyat untuk melengserkan semua pejabat sampai kepala negara sebagai upaya merevolusi atau meruntuhkan negara yang bersangkutan.

Ibnu Khaldun membagi setiap tahapan metamorfosis membutuhkan waktu 40 puluh tahun, sehingga sebuah negara 
yang mengalami tiga tahap dari lahir hingga kehancurannya membutuhkan waktu 120 tahun (Jurdi, 2008:117-118). Tabel di bawah akan menjelaskan secara sederhana tiga tahap metamorfosis negara berdasarkan teori ashabiyah:

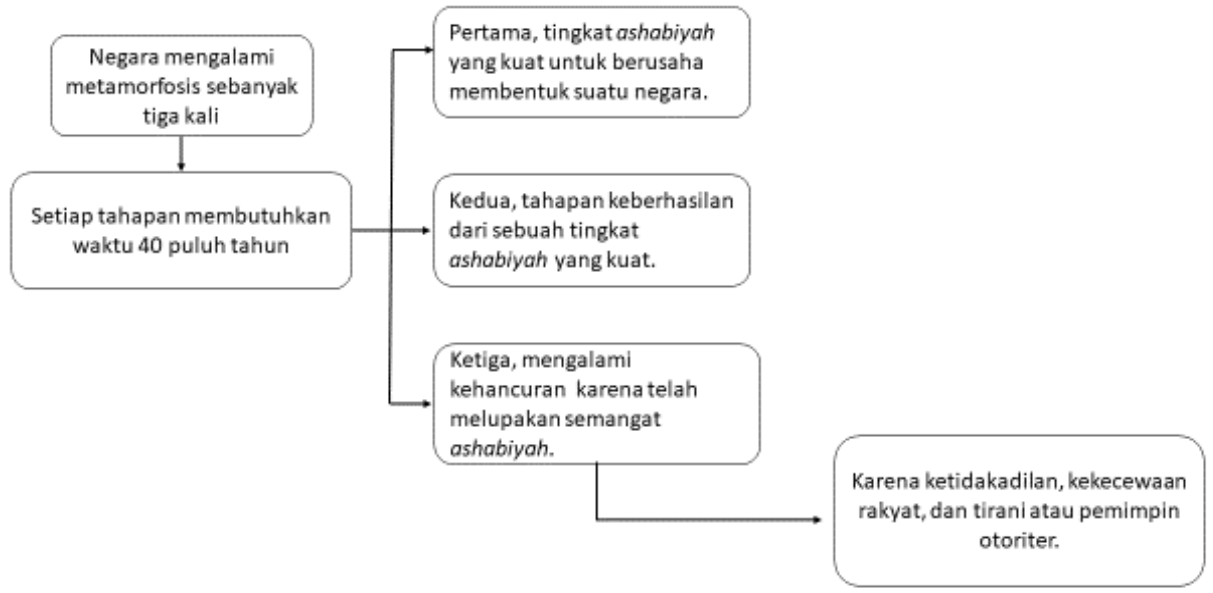

Gambar. 2. Tiga Tahap Metamorfosis Negara

Fokus di artikel ini adalah pada metamorposis tahap ketiga, bahwa kehancuran suatu negara terjadi karena ketidakadilan, kekecewaan rakyat karena rezim otoriter. Pemerintahan otoriter akan menghasilkan pelaksanaan negara yang keras dan kejam hingga akhirnya dapat menghancurkan negara tersebut. Menurut Ibnu Khaldun pelaksanaan kekuasaan secara lemah lembut adalah pelaksanaan kekuasaan yang terbaik. Kelemahlembutan itu harus pula disertai dengan ketegasan dalam menegakkan keadilan, serta berusaha untuk menciptakan situasi yang aman dan tentram sehingga rakyat dapat hidup dengan damai. Banyak hal yang harus diperhatikan penguasa untuk kepentingan rakyatnya agar rezim tidak berubah menjadi otoriter dan tidak berakhir diruntuhkan (Murdiono, 2006:40). 


\section{Filsafat Marx: Sebagai Landasan Ideologi atau Ashabiyah Uni Soviet}

Dalam teori ashabiyah, suatu negara dapat bersatu karena memiliki ikatan yang tidak terlihat, ikatan itu bisa dikatakan sebagai cita-cita bersama yang berwujud ideologi. Cita-cita negara Uni Soviet sejak awal didirikan oleh para founding fathers-nya adalah untuk menggantikan kekuasaan masyarakat feodal yang dianggap telah melakukan ketidakadilan hingga menimbulkan krisis pada negara dan terutama masyarakat kecil. Semangat revolusi tidak bisa dihindarkan, oleh sebabnya filsafat Karl Marx digunakan karena narasinya mendukung perjuangan masyarakat kecil, dan secara sah akhirnya menjadi ideologi Uni Soviet setelah feodalisme runtuh.

Filsafat Marx secara sederhana merupakan modifikasi dari dialetika idealis Hegel menjadi dialetika materialis. Tesisnya menyatakan bahwa kapitalisme akan menghadapi perlawan antitesis, yaitu kaum proletar untuk menghasilkan sintesis, yaitu sosialisme-komunis. Marx mengajukan proposisi bahwa sistem kapitalisme yang meletakan alat produksi di tangan kekuasaan kaum kapitalis mengakibatkan siklus krisis ekonomi. Dalam doktrin Marxis agar tidak terjadi krisis ekonomi, alat produksi harus berada di tangan kaum pekerja atau proletar (Yuana, 2010:253). Sementara di Kekaisaran Rusia, yang memiliki alat produksi adalah kaum feodal dan borjuis yang berasal dari kalangan bangsawan, tuan tanah, atau pemilik pabrik. Suatu fenomena yang bertentangan dengan teori Marx.

Bagi Marx, masyarakat di suatu negara hidup dalam sejarahnya sendiri, tetapi jika mereka membiarkan diri tertindas oleh golongan lain yang harus dilakukan adalah revolusi, karena jika terus tertindas maka masyarakat itu sejatinya telah mengalami keterasingan hidup sebagai umat manusia. Gagasan utama Marx adalah dialektika-materialisme yang merupakan kritik dan gabungan filsafat dielektis Hegel dan Materialisme Feurbarch. Gagasan Hegel yang mengatakan bahwa "yang nyata adalah apa yang bisa dipikirkan, dan yang bisa dipikirkan sudah pasti nyata", 
bagi Marx hal itu tidak membebaskan manusia dari keterasingan, bahkan justru semakin terasing di dalam dunia abstrak. Di sisi lain Feurbarch yang mengatakan bahwa "manusia adalah apa yang ia makan, dan seluruh hasil pemikiran manusia adalah refleksi dari kondisi materilnya" (Ramly, 2000:68), pendapat ini juga dari kritik Marx, karena baginya manusia tidak sepenuhnya tergantung pada materi, tetapi juga pada kehidupan sosialnya. Sebagaimana ide Hegel, ide Feurbarch juga dianggap Marx membuat manusia terasing.

Marx tidak mau ikut berspekulasi secara teoritis seperti yang dia tuduhkan pada filsuf-filsuf sebelumnya. Menurut Marx (dalam Ramly, 2000:114); "sejarah bersifat material, artinya sejarah mengacu pada kondisi-kondisi fundamental eksistensi manusia". Metode materialis Marx yang membedakan pandangannya dari pandangan Hegel. Berbeda pula dengan Feurbarch, karena objek perhatian Marx mencakup kehidupan sosial ekonomi manusia yang nyata terhadap pengaruh pandangan hidup manusia yang sebenarnya pada cara berpikir dan merasanya. Ide ciptaan Marx, seperti yang dikatakan Erich Fromm (dalam Permata, 2011:203):

"Berkebalikan dengan filsafat Jerman, yang menurut Marx turun dari langit ke bumi, filsafat Marx, menurutnya, justru naik dari bumi ke langit. Dengan kata lain, Marx tidak berangkat dari apa yang sedang dibayangkan, dipahami manusia sekarang ini, juga bukan dari apa yang telah diceritakan, dipikirkan atau dibayangkan, dan dipahami manusia pada zaman dahulu menuju manusia dalam bentuk fisik. Marx berangkat dari manusia yang nyata dan aktif dan berdasarkan proses kehidupannya yang nyata".

Karl Marx meninggal pada tanggal 14 Maret 1883, selama hidupnya dia belum pernah memimpin suatu gerakan revolusi yang dia pikirkan. Ada beberapa tokoh berpengaruh pasca meninggalnya Marx, yaitu Karl Kautsky yang tetap menginginkan adanya revolusi, dan Eduard Bernstein yang justru tidak 
mengharuskan adanya revolusi. Rosa Laxemburg, muncul sebagai tokoh yang menengahinya. Bagi Laxemburg revolusi akan datang secara spontan saat kaum buruh sadar. Pemikiran itu lalu ditolak Lenin, dengan terpengaruh Leon Trostky, karena bagi Lenin kaum buruh harus disadarkan bukan secara spontan, tetapi dengan dibentuknya partai yang terus-menerus memompakan kesadaran soal revolusi. Lenin dan Trostky selanjutnya menjadi dua tokoh penting dalam revolusi di Rusia tahun 1917 sebagai pencetus citacita bersama atau ideologi hingga terbentuknya Uni Soviet di tahun 1922.

\section{Lenin (Ashabiyah Tahap Pertama): Revolusi 1917 dan Terbentuknya Uni Soviet}

Dalam pandangan Ibnu Khaldun terbentuknya suatu negara tidak serta merta tanpa suatu usaha atau kejadian, memerlukan perjuangan yang tidak mudah dengan berbagai momentum yang dapat memberikan jalan untuk diperjuangkan oleh seluruh agen yang terlibat di dalamnya. Dalam teori ashabiyah, awal terbentuknya suatu negara adalah metamorfosis tahap pertama. Negara bukan hanya tentang wilayah geografis, tetapi juga masyarakat yang tinggal dan bagaimana kehidupan mereka, serta bagaimana mereka menciptakan tatanan sosial dan politiknya. Rusia yang wilayahnya membentang dari Eropa Timur sampai Asia Tengah sebelum Uni Soviet berdiri masih dikuasai oleh Monarki-Kekaisaran, dengan kaisarnya yang disebut Tsar. Masyarakatnya saat itu kebanyakan berprofesi sebagai petani dan buruh kasar.

Menjelang berakhirnya Perang Dunia I, pemerintahan Tsar hancur karena kehabisan tenaga, korupsi, dan kurangnya dukungan rakyat. Pada tahun 1914, tentara Tsar bertempur dengan peralatan yang jelek dan kurang terpimpin sehingga menderita serangkaian kekalahan yang fatal oleh tentara Jerman dan Austria. Bahan makanan menjadi semakin langka terutama di kota-kota (Groiler International, 1988:112). Pada bulan Januari, kaum buruh 
dan tentara di Petrogard sepakat membentuk lembaga perwakilan bersama, yang dalam bahasa Rusia disebut soviet. Soviet adalah gerakan revolusi yang dilakukan orang-orang kelas bawah untuk melengserkan Tsar. Orang-orang miskin berubah menjadi perusuh dan melakukan pemogokan kerja yang berlangsung di hampir seluruh kota. Serdadu dan polisi yang diperintahkan menembak para perusuh, justu malah memihak perusuh.

Pada tanggal 15 Maret 1917, Tsar menyerahkan kekuasaan eksekutif kepada Lvov. Di bawah kepemimpinan Lvov, Rusia masih mengalami krisis ekonomi hingga terjadi demontrasi besarbesaran yang menyebabkan Lvov mengubah kabinetnya. Tetapi kabinet baru ini tidak mampu mengubah apa-apa. Lenin yang waktu itu masih di Swiss, tidak tinggal diam mendengar hal tersebut, lalu langsung pergi ke Petrogard dan sampai pada 16 Juli 1917. Trostky yang berada di New York pun, langsung menyusul untuk mengorganisir Kaum Bolshevik. Dengan menggunakan kereta api hingga setibanya di Finlandia, Lenin langsung mengimbau "Semua kekuatan Soviet bersatu" (Praginanto, 1990:74). Pada tanggal 7 November 1917, atau masih Oktober bagi tanggalan Rusia Kuno, kaum Bolshevik, kaum sosialis radikal pimpinan Lenin dalam gerakan bernama Revolusi Oktober berhasil menguasai ibu kota Rusia, Petrogard (Magnis-Suseno, 2013:24).

Sistem pemerintahan baru kemudian dibentuk, dengan Soviet sebagai organ yang berkuasa. Kekuasaan eksekutif diserahkan kepada Komite Eksekutif Sentral Soviet, sedangkan legislatif diserahkan kepada Dewan Komite Serikat Rakyat. Lenin menjadi calon tunggal ketua dewan itu, sementara Trostky sebagai komisaris luar negri, dan Stalin sebagai komisaris masalah sukusuku bangsa. Soviet lain di luar Petrogard lalu melancarkan berbagai kerusuhan. Di Moskow terjadi peperangan selama seminggu, sampai akhirnya tentara pemerintah menyerah. Kaum revolusioner mendapatkan perlawanan sengit di Ukraina dan Finlandia yang ingin menciptakan negaranya sendiri, di mana akhirnya Finlandia saja yang bisa merdeka (Praginanto, 1990:75). 
Pemerintahan negara mulai direbut Lenin, dan Kaum Bolshevik diubah namanya menjadi Partai Komunis. Salah satu hal yang pertama-tama dikerjakan oleh Lenin adalah membawa Rusia keluar dari peperangan. Di dalam negeri, oposisi terhadap Pemerintahan Komunis mulai tumbuh, mereka adalah kaum pengusaha, pemilik tanah, bangsawan, dan Gereja Ortodox, serta para perwira tentara kerajaan yang termasuk di dalam Tentara Putih. Pada 1917-1923 terjadi perlawanan Tentara Putih yang masih berpihak pada Monarki Rusia, tetapi dapat dikalahkan oleh Tentara Merah Komunis pimpinan Trostky.

Pada Juni 1918, Tsar bersama istri dan anaknya dibunuh di Yekaterinburg, Siberia. Dengan terbunuhnya Tsar, Lenin secara absolut berhasil menggulingkan kekuasaan kaum feodal di Rusia, dia mendirikan sebuah negara sosialis-komunis yang dinamai Uni Soviet pada 30 Desember 1922, dirinya sendiri diangkat sebagai penguasa tertinggi baru. Paham Marxisme yang dikembangkan Lenin disesuaikan dengan kondisi Rusia, dengan demikian Marxisme tidak lagi murni dari filsafat Marx, dan alasan Lenin melakukan hal ini jika dilihat dari teori ashabiyah adalah untuk mempermudah kontrol sosial yang mempersatukan masyarakat dengan kondisi saat itu.

Ketika kaum komunis mulai memegang kekuasaan, mereka mengambil alih kepemilikan pabrik yang besar, lahan pertanian, bank, barang kebutuhan rakyat, dan jaringan jalan raya. Mereka juga melarang perdagangan swasta. Lenin (dalam Stepanova, 2004:56) mengatakan:

"Kaum proletar akan menggunakan supremasi politiknya untuk merebut secara paksa, sedikit demi sedikit seluruh modal kaum borjuis, memusatkan semua peralatan produksi di tangan negara, yaitu kaum proletar yang diorganisasikan sebagai kelas yang berkuasa dan menambah jumlah kekuatan-kekuatan produktif secepat mungkin negara, yang diorganisasikan sebagai kelas yang berkuasa, yaitu kediktatoran proletariat". 
Lenin menyadari jika negara mengambil alih sepenuhnya usaha rakyat maka akan menyebabkan kekecewaan politik dan ekonomi kepada petani dan pedagang (swasta kecil), untuk itu dibuatlah NEP (New Economy Policy), dengan peraturan ini petani dan pengusaha kecil diizinkan menjual produknya dengan harga berapa saja yang diharapkan oleh mereka. Tidak lama, Lenin meninggal pada tahun 1924, atau hanya dua tahun saja dia berkuasa dan belum sempat sama sekali melihat negaranya menjadi negara industri-sosialis. Tanpa Lenin walaupun Kekaisaran Rusia sedang mengalami krisis, kemungkinan tidak ada tokoh sebesar dia yang melakukan ashabiyah tahap pertama untuk mempersatukan masyarakat yang ingin melakukan revolusi, dan tanpa revolusi maka Uni Soviet tidak akan pernah terbentuk.

Tiga bulan setelah meninggalnya Lenin, suksesornya yaitu Stalin memberikan kuliah "Tentang Dasar-Dasar Leninisme" di Universitas Swerdlosvk. Dalam kuliah itu dia membekukan ajaran Lenin sebagai "Leninisme" dan dengan demikian sekaligus menobatkan diri sebagai pewaris Lenin (Magnis-Suseno, 2016:225). Sebelumnya Stalin terlibat konflik suksesi bersama Trostky, banyak anggota partai yang mendukung Trostky sebagai pengganti Lenin karena kesuksesannya membawa Tentara Merah menang dalam perang saudara Rusia. Tahun 1927 Stalin berhasil mengeluarkan Trostky dari partai, dan dua tahun kemudian diusir ke luar negeri. Pada 1940, Trostky dibunuh bersama anggota keluarganya di Meksiko. Setelah Trosky mati, Stalin menjadi pemimpin mutlak Uni Soviet dan telah menciptakan rezim pemerintahan yang memajukan negaranya dengan cepat, tetapi di waktu yang sama juga mulai muncul suasana otoriter. 


\section{Stalin (Ashabiyah Tahap Kedua): Kultus dan Negara Adidaya Setelah Perang Dunia II}

Marxisme-Leninisme oleh Stalin dijadikan filsafat wajib yang harus dipelajari di sekolah dan universitas-universitas di Uni Soviet. Filsafat Soviet mengklaim tiga ciri khas, yaitu bahwa Marxisme-Leninisme sudah pasti benar, berlaku secara universal dan bersifat ilmiah. "Pasti benar" sebenarnya sama dengan "dogmatis". Dogmatis berarti menyatakan bahwa dalil-dalil Marxisme-Leninisme merupakan kebenaran yang tidak bisa diperdebatkan lagi. Pada 1931 Stalin menetapkan bahwa prinsipprinsip Marxisme-Leninisme tidak memerlukan diskusi lanjutan. Marxisme-Leninisme bukan lagi sekedar teori atau filsafat, melainkan penemuan hukum-hukum objektif tentang perkembangan sosial umat manusia. Engels sudah mendahului mengartikan dengan meyakini bahwa ide Marx sebagai penemuan hukum-hukum objektif terhadap masalah sosial seperti layaknya ilmu alam. Pandangan ini merupakan salah satu puncak scientism, kepercayaan bahwa kehidupan manusia dapat dipastikan dengan dalil-dalil sepasti hukum fisika. Dogmatisme itu hakiki bagi komunisme karena kalau dalil-dalil dasarnya masih terbuka bagi falsikasi di kemudian hari, kepemimpinan partai komunis kehilangan dasar kekuasaannya di atas masyarakat (MagnisSuseno, 2013:78).

Sebagai sebuah dogma yang harus dipercayai oleh masyarakat maka Marxisme-Leninisme sama saja telah berubah menjadi agama. Dalam pandangan Marx, agama yang saat dirinya hidup banyak dianut orang Eropa dianggap sebagai candu. Fantasi agama adalah sebuah bentuk pelarian dari kehidupan nyata. Manusia telah memproyeksikan kebahagiaannya sebagai sesuatu yang dapat dirasakan setelah kehidupan ini (Misbah, 2015:199). Sementara saat Lenin masih berkuasa, dia memang tidak melarang agama, tetapi cenderung tidak menyukainya. Marx maupun Lenin, keduanya adalah orang ateis. Lenin sendiri sudah tidak beragama sejak muda, bahkan jika dibandingkan Marx yang menganggap agama hanya sebagai candu, Lenin menganggapnya seperti wiski 
murahan. Dalam sebuah karangan Lenin (dalam Magnis-Suseno, 2016:28) menulis:

"Merebut hati buruh lebih penting dibandingkan menyebarkan ateisme, oleh karena itu orang yang bukan ateis pun boleh masuk partai komunis. Partai harus memperhatikan prasangka-prasangka religius kaum buruh, jangan sampai mereka terasing dari partai karena sikap partai yang anti agama".

Lenin sebetulnya menghargai kebebasan beragama, tetapi propaganda ateis akan selalu berbarengan dengan propaganda komunis. Berbeda dengan Lenin, Stalin menyadari bahwa suatu kepercayaan terhadap yang paling benar itu penting. Seperti pandangan Ibnu Khaldun, agama memiliki pengaruh dalam persatuan masyarakat secara identitas spiritual. Alih-alih bersandar pada agama-agama yang telah ada, Stalin justru menciptakan sebuah agama baru dari ajaran yang bersumber dari orang-orang yang sama sekali tidak mempercayai adanya Tuhan, dan menganggap inilah ajaran paling benar untuk menjalani hidup di dunia. Stalin sekaligus mengklaim sebagai pewaris tertinggi ajaran itu, dengan kata lain telah menciptakan kultus terhadap dirinya yang akan menimbulkan kesetiaan dan fanatisme buta. Dalam ashabiyah, hal ini adalah suatu yang bersifat negatif, dan selanjutnya dapat dilihat dari bagaimana Stalin menjalankan kekuasaanya.

Pada dekade 1930-an, Stalin curiga dengan orang-orang di dalam atau di luar partainya. Tahun 1936-1939, terjadi genosida terbesar dalam sejarah Rusia. Para pejabat partai, pahlawan Bolshevik yang sudah tua, insinyur, ilmuwan, ahli ekonomi, penulis, perwira militer dan banyak lagi ditangkap dengan tuduhan menggulingkan Soviet atau memulihkan kapitalisme. Mereka dihukum mati atau dikirim ke kam kerja paksa yang kondisinya demikian buruk hingga banyak dari mereka meninggal, hal ini sesuai dengan teori ashabiyah yang menyebut bahwa elit pemerintah yang curiga akan mempertahankan 
kekuasaannya dengan cara apapun, hingga menjadi rezim otoriter. Solzhenitsyn (dalam Permata, 2011:2016) menggambarkan otoritarianisme Uni Soviet ketika pemerintahan Stalin, sebagai berikut:

"Kam khusus pastilah merupakan salah satu ciptaan kesayangan Stalin di masa tuanya. Setelah melakukan begitu banyak eksperimen dalam hukuman dan reedukasi, akhirnya ia bisa mendapatkan bentuk hukuman yang sempurna: sebuah organisasi yang ringkas dan terdiri dari orang-orang tanpa wajah yang diwakili angka-angka, yang secara psikologis telah dicerabut dari tanah air yang telah melahirkan mereka, organisasi yang memiliki pintu masuk tapi tidak memiliki pintu keluar, yang hanya melahap musuh-musuh rakyat dan menghasilkan barang-barang industri dan mayatmayat".

Selama teror ini berlangsung, indutrialisasi yang digagas Stalin tetap maju berkembang dengan cara menaikan jam kerja para buruh kasar. Tahun 1940, Soviet menghasilkan lebih banyak besi, baja, batu bara dan minyak daripada awal berdirinya, sekaligus banyak kehilangan buruh kasar yang meninggal karena kelelahan dan kelaparan. Hanya Amerika Serikat dan Jerman yang mengungguli dalam hal produksi baja. Tetapi tidak lama terjadi Perang Dunia II, yang berpengaruh dalam perekonomian dan pertahanan Uni Soviet.

Tahun 1942-1943 tentara NAZI dihadang di Ukraina dan terjadi pertempuran sengit di Stalingrad. Tentara Soviet berhasil mendesak tentara NAZI Jerman, hingga berhasil masuk ke Berlin pada Mei 1945. Selama perang itu hampir 20.000.000 masyarakat Soviet terbunuh. Setelah perang berakhir Uni Soviet menerima bantuan sewa pinjam oleh Amerika Serikat hampir senilai $\$ 11.000 .000$ untuk menutupi kehancuran ekonominya. Dengan modal ini, Stalin berusaha untuk memulihkan perekonomian dan sektor industri. Stallin tidak membiarkan kecemasan perang 
menghantui rakyat, tetapi mendorong mereka untuk lebih giat bekerja lagi (dalam Grolier International, 1988:113-115). Selain itu Uni Soviet juga berhasil merebut wilayah Kekasiaran Rusia yang hilang selama Perang Dunia I. Wilayah yang dimaksud meliputi Polandia Timur, Bessarabia (bagian Rumania), dan tiga negara Laut Baltik.

Dengan kejadian di atas pengaruh Uni Soviet menjadi sangat kuat di Eropa Timur. Sebagian negara yang dibantu Uni Soviet untuk mengusir Tentara NAZI meyakinkan diri mendukung partai komunis di negaranya masing-masing. Pada tahun 1948 beberapa negara yaitu Bulgaria, Albania, Cekowslowakia, Hongaria, Polandia, sampai Jerman Timur berhasil diperintah oleh Rezim Komunis ala Uni Soviet. Hanya Yugoslovia yang waktu itu diperintah Josip Broz Tito tidak setuju dengan komunisme Soviet, walaupun mereka juga berideologi Marxis. Pada waktu ini Uni Soviet berhasil mencapai ashabiyah tahap kedua, kuat secara ekonomi dan pengaruh terhadap negara-negara lain.

Berbeda dengan perkiraan Ibnu Khaldun yang mengatakan tahap kedua atau kemajuan suatu negara akan diperoleh 40 tahun setelah terbentuknya, Uni Soviet di bawah kekuasaan Stalin ternyata bisa maju hanya dalam kurun waktu sekitar 26 tahun, dari tahun 1922 ke puncaknya di tahun 1948. Di lain hal, Ibnu Khaldun benar bahwa fanatisme buta yang dijalankan Stalin lewat pendogmaan Marxisme-Leninisme adalah sesuatu yang negative karena menjadikan dirinya sebagai kepala negara kultus dan otoriter.

Pengaruh kuat Uni Soviet di kawasan Eropa Timur ternyata tidak disambut gembira oleh Amerika Serikat. Sebelum Perang Dunia II terjadi hubungan ideologis kedua negara ini sudah saling bertentangan, dan hanya reda karena memiliki musuh bersama yaitu NAZI Jerman. Pemerintah Amerika Serikat lalu mendesak negara-negara Eropa Timur untuk memilih pemerintahannya sendiri, serta memberi dukungan terhadap Yunani dan Turki untuk menghadapi ancaman Uni Soviet. Di tahun 1949, Amerika Serikat bersama negara-negara di Eropa Barat, Kanada, dan 
Yunani membentuk Organisasi Pertahanan Atlantik Utara atau NATO. Kejadian ini semakin membuat Uni Soviet curiga, hingga dua tahun setelah Stalin meninggal, yaitu pada 1955 didirikanlah organisasi tandingan bernama Pakta Warsawa dengan anggota lainnya adalah Jerman Timur, Hongaria, Cekoslowakia, Rumania, Bulgaria dan Albania.

Pertentangan antara NATO dan Pakta Warsawa, dikenal juga dengan pertentangan Blok Barat dengan Blok Timur. Amerika Serikat dan Uni Soviet yang telah menjadi dua negara adidaya jelas merupakan pemimpin masing-masing dua blok tersebut. Pengaruh ideologis mereka bahkan tidak hanya dirasakan di Eropa Barat atau Eropa Timur, tetapi sampai pada negara-negara di Amerika Latin dan Asia. Berbagai kejadian seperti perang saudara di Kuba, Korea yang terpisah menjadi dua negara, konflik Vietnam, hingga Peristiwa Madiun 1948 dan G30S 1965 di Indonesia bisa dikatakan sebagai akibat dari pertentangan ideologis yang diciptakan mereka. Hal ini menjadi semakin rumit karena karena kedua blok berkeinginanan untuk menguasai senjata nuklir yang dalam sejarah dikenal dengan Perang Dingin.

\section{Setelah Stalin (Ashabiyah Tahap Ketiga): Partai Otoriter dan Keruntuhan Uni Soviet}

Setelah Stalin meninggal pada tahun 1953, pemimpin Uni Soviet dipercayakan kepada Georgy Malenkov. Tahun 1955 Malenkov kembali digantikan oleh Nikita Khrushchev yang menjadi pemenang dalam pemilihan pemimpin Uni Soviet. Salah satu peristiwa paling mencolok selama pemerintahan Khruschev adalah saat dia memberikan pidato pada Kongres Partai Komunis Uni Soviet ke-20 di tahun 1956 yang dengan berani mengatakan bahwa saat pemerintahan Stalin telah terjadi penangkapan, penyiksaan, dan pembunuhan terhadap orang-orang yang dicurigai yang tak terbilang jumlahnya. Peristiwa tadi sangat tabu disampaikan kepada publik di era Stalin, karena katakutan dan penghormatan rakyat karena pengkultusan kepada dirinya. Setelah pidato itu usai dan menjadi berita utama di media massa 
Uni Soviet, terjadi suatu kampanye untuk menghilangkan Stalinisme, pencabutan patung dan gambar Stalin, bahkan jasad Stalin dikeluarkan dari kuburnya di pemakaman Lapangan Merah.

Pada tahun 1964, Khruschev digantikan Leonid Brezhnev. Pada masa ini rakyat diperbolehkan bersuara lebih bebas dibandingkan saat Stalin berkuasa, bahkan diperbolehkan juga mengkritik kebijakan pemerintah dengan kode etik tertentu, tetapi masih tidak boleh mengkritik Partai Komunis. Pada masa ini juga terjadi perubahan Konstitusi 1936 dengan Konstitusi Baru 1977, yang memberikan hak istimewa ke pada Partai Komunis Uni Soviet (PKUS) sebagai partai satu-satunya (Bujono, 1990:71), hal ini adalah bentuk ashabiyah negatif yang akhirnya merusak terciptanya keselarasan. Hak istimewa terhadap Partai Komunis akhirnya akan menciptakan rezim otoriter yang tidak berbeda dengan masa Stalin.

Pada tanggal 10 November 1982, Brezhnev meninggal dan dua hari kemudian digantikan Yuri Andropov sampai meninggalnya pada tanggal 9 Februari 1984. Pemerintahan dilanjutkan Konstantin Chemenko pada tanggal 13 Februari 1984 sampai meninggalnya pada 10 Maret 1985. Sehari setelahnya, pada tanggal 11 maret 1985, Mikhail Gorbachev menjadi pemimpin baru sekaligus terakhir bagi Uni Soviet.

Perubahan paling besar terjadi pada tahun 1985 saat Mikhail Gorbachev berkuasa adalah keinginannya meminimalisir kekuasaan absolut Partai Komunis, dengan membuka jalan pada demokrasi multipartai. Kebijakan Gorbachev tadi tidak sematamata karena keinginan dirinya, tetapi juga karena ada perubahan situasi politik dan ideologi yang terjadi di kawasan Eropa Timur saat itu. Selain itu pemerintah komunis yang otoriter dianggap mayoritas masyarakat Uni Soviet tidak tepat dengan situasi perkembangan ekonomi dunia di akhir abad ke-20, dan hal ini terjadi karena kekecewaan rakyat pada hak istimewa Partai Komunis. Fakta tadi serupa dengan apa yang dipikirkan Ibnu Khaldun, bahwa keistimewaan pada satu kelompok akan 
mendapatkan perlawanan hingga keruntuhan, dan begitulah apa yang dengan Uni Soviet.

Keruntuhan komunisme atau Marxisme-Leninisme yang diawali kekecewaan masyarakat Uni Soviet bisa dikatakan terjadi karena dulu Stalin menjadikannya sebagai dogma. Tidak ada ruang diskusi mengenai ideologi komunis setelah pendogmaanya, padahal jika Marx diposisikan sebagai seorang filosof maka filsafatnya adalah ilmu pengetahuan. Mengutip Ibnu Khaldun dalam Muqqodimah (2000:56):

“Ilmu pengetahuan yang tidak berkembang, maka yang ada hanyalah syarah (komentar), saking tidak berkembangnya syarah itu dikomentari menjadi hasiyah (kelanjutan dari komentar saja) dan kemudian hasiyah dikemontari kembali menjadi taqlid".

Kata "taqlid" dalam bahasa Arab dapat diartikan sebagai "mengikuti tanpa mengetahui sumbernya". Istilah ini biasanya digunakan terhadap kebiasaan atau tradisi yang dipercayai masyarakat tanpa dipertanyakan kembali maksud dan asalusulnya. Marxisme-Leninisme yang telah dijadikan dogma berarti telah menjadi taqlid, filsafat Marx yang harusnya bisa terus relevan di Uni Soviet pada akhirnya berhenti berkembang karena diskusi terhadapnya telah dilarang, dan hal inilah yang menjadi penyebab keruntuhannya.

Hal lain yang juga perlu dipertimbangkan bahwa Uni Soviet adalah gabungan dari beberapa daerah di Eropa Timur sampai Asia Tengah atau Eurasia yang berhasil ditaklukan lewat ideologi komunis. Namun dinamisme perkembangan di tubuh Uni Soviet akhirnya gagal menyatukan 15 negara bagian yang diusulkan oleh pendirinya (Brzezinski, 1990:13). Setiap orang pada dasarnya adalah warga negara Soviet, tetapi sekaligus dia termasuk ke salah satu dari 100 bangsa yang berbeda-beda (Groiler International, 1998:72). Terjadi krisis identitas, dan keinginan memerdekakan diri untuk lepas dari Rusianisasi, yang akhirnya 
menjadi negara-negara baru merdeka setelah runtuhnya Uni Soviet pada tanggal 21 desember 1991.

Jika dicermati runtuhnya Uni Soviet, dengan pemikiran Ibnu Khaldun hampir tepat menyatakan waktunya di tahap ashabiyah ketiga. Dalam tahap ashabiyah ketiga suatu negara yang mengalami puncak kejayaan diperkirakan akan hancur 40 tahun kemudian. Uni Soviet mencapai puncak kejayaannya di tahun 1948, dan akhirnya resmi runtuh di tahun 1991, berarti dalam jangka waktu 43 tahun. Ibnu Khaldun juga tepat menyatakan bahwa negara bisa runtuh karena ashabiyah negatif yang menyebabkan kekecewaan rakyat akibat fanatisme buta dan rezim otoriter dengan perjalanan politik Uni Soviet. Tetapi umur Uni Soviet hanya sekitar 69 tahun, berbeda dengan perkiraan Ibnu Khaldun bahwa suatu negara terbentuk sampai hancur memerlukan 120 tahun.

\section{Refleksi Terhadap Runtuhnya Uni Soviet dan Ashabiyah Negatif}

Artikel ini ditulis bukan untuk sekedar memberikan informasi mengenai sejarah berdiri hingga runtuhnya negara Uni Soviet ataupun kegagalan pendogmaan Marxisme. Harus ditegaskan bahwa kegagalan peradaban bisa terjadi di negara yang menggunakan ideologi manapun, karena itu keruntuhan Uni Soviet yang telah dianalisis dengan teori ashabiyah pada pembahasan sebelumnya diharapkan bisa menjadi refleksi terhadap diskursus sosio-politik dewasa ini.

Ada dua masalah yang bisa direflesikan mengenai keruntuhan Uni Soviet, yaitu eksklusivisme dan kultus yang menimbulkan ashabiyah bersifat negatif dalam wujud rezim otoriter. Eksklusivisme di Uni Soviet dilaksanakan oleh Partai Komunis karena menjadi partai tunggal, dan memiliki hak istimewa seperti peraturan seluruh pejabat dan kepala negara harus berasal dari anggota partai. Eksklusivisme selalu menimbulkan masalah yaitu truth claim bahwa kebenaran 
dianggap hanya dimiliki oleh satu kelompok (dalam Latuheru, et al, 2020:152). Setelah Stalin menjadikan Marxisme-Leninisme sebagai dogma, Partai Komunis bisa menyatakan truth claim terkait seluruh kebijakan dan praktik politiknya karena ideologi partai pasti benar dan tidak bisa diperdebatkan. Stalin yang menggantikan Lenin menjadi kepala negara dan masih anggota Partai Komunis, bisa mudah menjadikan dirinya sebagai seorang kultus karena dianggap sebagai pewaris atau representasi nyata atas dogma ciptaannya sendiri. Dengan distribusi kekusaan eksklusif dipegang satu kelompok saja, dan pengkultusan terhadap kepala negara maka pemerintahan itu menjadi rezim otoriter.

Apakah hanya negara berideologi komunis atau Marxis yang bisa dikuasai secara ekslusif oleh satu golongan atau partai dan kepala negara kultus yang otoriter? Jawabannya tentu saja tidak, karena setiap ideologi adalah ashabiyah yang berarti niat awalnya untuk membangun persatuan masyarakat dan memajukan peradaban di tanah airnya. Bagaimana ashabiyah itu menjadi positif dan negatif pada akhirnya ditentukan oleh praktik politik yang dijalankan pihak yang memiliki akses terhadap politik praktis (politisi) dan peran aktif masyarakatnya.

Runtuhnya Uni Soviet di tahun 1991 secara khusus membawa perubahan besar bagi negara-negara pecahan Soviet dan Eropa Timur (Kartini, 2014:28). Namun secara umum keruntuhan Uni Soviet juga telah membuka jalan terhadap diskursus reformasi dan demokrasi negara lain yang dikuasai oleh rezim otoriter dan kepala negara kultus di luar wilayah Eropa Timur. Indonesia adalah salah negara yang mengalami reformasi pasca runtuhnya Uni Soviet.

Indonesia di masa Orde Baru yang secara ideologi anti terhadap komunisme, namun secara praktik politiknya tidak jauh berbeda dengan Uni Soviet. Presiden Soeharto adalah sosok yang otoriter dan menjadikan dirinya sebagai seorang kultus. Otoritarianisme dan kultus yang diciptakan rezim Orde Baru bisa menghantarkan Soeharto menjabat sebagai kepala negara selama 
31 tahun, dan selama itu juga tidak lepas dari kejahatan kemanusiaan seperti Stalin. Namun si sisi yang lain, karena praktik politik yang dijalankan Orde Baru adalah otoriter dan merupakan wujud ashabiyah negatif maka terjadilah krisis yang pada akhirnya meruntuhkan pemerintahannya sendiri di tahun 1998 lewat berbagai gerakan yang menuntut reformasi. Sistem pemerintahan Orba dianggap tidak relevan dengan perkembangan masyarakat Indonesia di akhir dekade 1990an, mirip seperti komunisme yang dianggap tidak relevan oleh masyarakat Soviet di akhir dekade 1980an.

Di penghujung 2010 hingga awal 2011, kawasan di Afrika Utara dan Timur Tengah mengalami pergolakan politik yang dikenal dengan istilah Arab's Spring. Suatu gerakan yang bertujuan untuk melengserkan kekukuasan otoriter yang dimulai dari Tunisia menyusul Mesir, Aljazair, Yaman, Bahrain, Libya dan negara-negara Arab lainnya. Namun hanya beberapa saja yang berhasil menjatuhkan kepala negaranya seperti Tunisia, Mesir dan Libya (Atthahara, 2017:155-156). Semua negara yang disebut di paragraf ini tidak ada yang berideologi komunis, tetapi otoritarianisme yang merupakan representasi dari ashabiyah negatif tetap terjadi.

Eksklusivisme dan kultus masih terjadi di masyarakat sekarang ini. Di Indonesia pada Pilpres 2019, masyarakat yang aktif di sosial media sempat (atau masih) terbagi menjadi dua kubu, karena masing-masing kubu mengkultuskan calon yang mereka dukung sekaligus menganggap bahwa mereka telah menyatakan kebenaran, sementara yang memiliki pilihan berbeda dianggap tersesat. Tentu saja masalah Uni Soviet dan Pilpres Indonesia 2019 adalah hal yang berbeda, namun memiliki kesamaan yaitu merasa kebenaran hanya milik kelompoknya sendiri.

Mempelajari sejarah runtuhnya suatu negara, rezim atau sosok otoriter haruslah menjadi kritik terhadap diri, karena kemungkinan kesalahan dari orang terdahulu walaupun sedikit bisa tanpa disadari dilakukan di masa sekarang. Mengklaim 
kebenaran karena ideologi atau dogma tertentu, dan mengkultuskan politisi atau seorang tokoh adalah representasi dari ketidakdewasaan menghadapi rumitnya masalah sosio-politik yang ada. Keaktifan masyarakat terhadap dinamika politik di masa sekarang ini, harus juga dibarengi oleh kesadaran mengenai bahayanya eksklusivisme dan kultus.

\section{KESIMPULAN}

Dari semua pembahasan yang telah disampaikan, kesimpulannya adalah bahwa Uni Soviet mengalami tiga tahap metamorfosis sesuai dengan teori ashabiyah Ibnu Khaldun. Tetapi rentang waktu antar tahap-tahap yang diperkirakan terjadi setiap 40 tahun, ternyata tidak cukup akurat. Revolusi yang diawali tahun 1917 akibat krisis Kekaisaran Rusia, hanya butuh waktu lima tahun saja hingga Lenin bisa menciptakan pemerintahan atau negara baru bernama Uni Soviet di tahun 1922, dan hanya butuh 26 tahun bagi penerusnya Stalin untuk mencapai kejayaanya. Perkiraan waktu Ibnu Khaldun pada dua tahap awal memang tidak sesuai rentang waktu yang diraih Uni Soviet, tetapi di metamorphosis tahap ketiga, mengenai keruntuhan negara, Ibnu Khaldun hampir tepat memperkirakannya dengan apa yang terjadi pada Uni Soviet yang diresmikan bubar tahun 1991 yang jika dimulai dari 1948, maka terhitung 43 tahun setelah masa jayanya.

Proses keruntuhan Uni Soviet sesuai dengan yang diteorikan Ibnu Khaldun, bahwa suatu negara bisa runtuh karena praktik ashabiyah yang bersifat negatif. Dogmatisme terhadap ajaran Marxisme-Leninisme yang dilakukan Stalin adalah suatu yang menimbulkan kesetiaan, fanatisme buta, kultus hingga rezim otoriter, dan hal tersebut menghalangi terjadinya ashabiyah positif dengan terpenuhinya kewajiban kepada sesama yang mendorong keselarasan. Pendogmaan terhadap Marxisme-Leninisme juga menyebabkan ajaran yang sebenarnya filosofis ini tidak berkembang, hingga akhirnya dianggap tidak relevan dengan 
keadaan masyarakat. Masyarakat kecewa terhadap pemerintahan otoriter akibat hak istimewa yang diberikan kepada Partai Komunis Uni Soviet. Singkatnya teori ashabiyah Ibnu Khaldun memang tidak tepat dalam memperkirakan waktu suatu negara dari terbentuk, mengalami kemajuan, sampai pada keruntuhannya, yang dalam hal ini merujuk pada sejarah Uni Soviet. Umur Uni Soviet dari berdiri, menjadi negara adidaya (hadhiri), hingga runtuhnya hanya berlangsung sekitar 69 tahun, berbeda dengan perkiraan teori ashabiyah yang menyebut 120 .

Otoritarianisme yang merupakan representasi dari ashabiyah negatif yang terjadi di Uni Soviet tidak berarti membuktikan bahwa hanya negara komunis saja yang menjalankannya. Negaranegara non-komunis bahkan yang anti-komunis sekalipun bisa terjebak dalam kekuasaan rezim otoriter, sebagai contohnya Indonesia di masa Orde Baru. Rezim otoriter timbul karena eksklusivisme dan kultus, yang mana kedua hal tersebut masih menjadi masalah dalam praktik politik saat ini. Apa yang harus dilakukan setelah mengetahui keruntuhan rezim otoriter dan tokoh kultus di masa lalu (melalui sejarah) adalah dengan terbuka pada kritik diri untuk tidak mengulangi kesalahan yang sama di masa sekarang hingga masa yang akan datang.

\section{DAFTAR PUSTAKA :}

Arisandi, H. (2015). Buku Pintar Pemikiran Tokoh-Tokoh Sosiologi Dari Klasik Sampai Modern. IRCiSoD.

Atthahara, H. (2017). Demokrasi di Negara Muslim: Transisi Menuju Demokrasi Pada Masa Reformasi 1998 di Indonesia dan Gejolak Revolusi Mesir 2011. Jurnal Politikom Indonesiana, 2(2), 155-167.

Brzezinski, Z. (1990). Kegagalan Besar (Munculnya dan Runtuhnya

Komunisme Dalam Abad Kedua Puluh). PT Remaja Rosdakarya. Bujono, B. (1990). Sampai di Sini Marx, Lenin, dan Partai Komunis. Tempo, 17 Februari. 
Fajar, A. S. M. (2018). Perspektif Ibnu Khaldun Tentang Perubahan Sosial. SALAM: Jurnal Sosial Dan Budaya Syar'I, 6(1), 1-12.

Groiler, I. (1988). Negara dan Bangsa Jilid 7 Eropa, Amerika Utara. Widyadara.

Giddens, A. (2000). Jalan Ketiga. PT Gramedia.

Isma'il, F. F., \& Mutawalli, A. H. (2016). Berfilsafat Itu Gampang. IRCiSoD.

Ilham, M. (2016). Konsep 'Ashabiyah Dalam Pemikiran Politik Ibnu Khaldun. Jurnal Politik Profetik, 4(6), 1-13.

Jurdi, S. (2008). Sosiologi Islam Elaborasi Pemikiran Ibn Khaldun. Bidang Akademik UIN Sunan Kalijaga.

Kardelj, E. (2011). Jalan Menuju Sosialisme Sedunia. Terawang Press.

Kartini, I. (2014). Aneksasi Rusia di Krimea dan Konsekuensi Bagi Ukraina. Jurnal Politik, 11(2), 27-41.

Kurniawati. (2015). Pendidikan Sejarah dalam Kurikulum di Republik Jerman: A Lesson Learned. Jurnal Pendidikan Sejarah, $4(1), 1-13$.

Khaldun, I. (2000). Muqoddimah, Terj. Ahmadie Thoha. Pustaka Firdaus.

Khoiruddin. (2016). Analisis Teori Ashabiyah Ibn Khaldun Sebagai Model Pemberdayaan Ekonomi Umat. Asas: Jurnal Hukum Dan Ekonomi Islam 8(1), 66-75.

Latuheru, A. C., Lattu, I. Y. M., \& Tampake, T. R. (2000). Pancasila Sebagai Teks Dialog Lintas Agama Dalam Perspektif HansGeorg Gadamer dan Hans Kung. Jurnal Filsafat, 30(2), 150180.

Magnis-Suseno, F. (2016). Dalam Bayang-Bayang Lenin Enam Pemikir Marxisme dari Lenin sampai Tan Malaka. PT Gramedia.

Magnis-Suseno, F. (2013). Dari Mao Ke Marcuse. PT Gramedia. Magnis-Suseno, F. (2016). Pemikiran Karl Marx Dari Sosialisme Utopis ke Perselisihan Revisionisme. PT Gramedia.

Marx, K., \& Engels, F. (2009). Manifesto Partai Komunis. Rowland Literature. 
104 Jurnal Filsafat, Vol. 31, No. 1, Februari 2021

Misbah, M. (2015). Agama Dan Alienasi Manusia (Refleksi Atas Kritik Karl Marx Terhadap Agama). Jurnal Komunika, 9 (2), 196-206.

Muawiyah, R. A. (2000). Peta Pemikiran Karl Marx (Materialisme Dialekttis dan Materialisme Historis. LKiS.

Mujiyati, N. K., \& Sunarjo. (2016). United States During The Cold War 1945-1990. Jurnal Historia, 4(1), 39-54.

Murdiono, M. (2006). Citra Penguasa Ideal dalam Perspektif Politik Ibnu Khaldun Dan Relevansinya Bagi Kepemimpinan Di Indonesia. Jurnal Penelitian Humaniora, 11(2), 33-46.

Murtiningsih, W. (2013). Para Filsuf Dari Plato Hingga Ibnu Bajjah. IRCiSoD.

Mutarmadji. (2009). Kegagalan Perang Dingin Antar Dua Negara Adidaya: Faktor Penyebab Dan Implikasinya. Humanika, 9(1), 81-92.

Nonci, M. H. (2012). “Al Inayah Dan Al-Iktiara Dalam Teori Filsafat Materialisme". Sulesana, 7(2), 33-48.

Permata, H. (2011). Filsafat Dan Konsep Negara Marxisme. Jurnal Filsafat, 21(3), 200-223.

Praginanto. (1990). Dari Bunga Api Sampai Gorbachev. Tempo, 17 Januari.

Ramly, A. M. (2000). Peta Pemikiran Karl Marx (Materialisme Dialektis dan Materialisme Historis). LKiS.

Sindhunata. (2000). Die neue Unurbersichtlichkeit. Basis. 1(2).

Stepanova, E (2004). Karl Marx Nabi Kaum Proletar. Mata Angin.

Yuana, K. A. (2010). The Greatest Philosophers 100 Tokoh Filsuf Barat dari Abad 6 SM -Abad 21 yang Menginspirasi Dunia Bisnis. C.V Andi Offset. 